\section{Identification of metabolic and enzymatic pathways in the phosphorus cycle using triple oxygen isotope systematics}

\author{
DANIEL HERWARTZ ${ }^{1}$, ANDREAS PACK ${ }^{2}$, TOMMASO DI \\ ROCCO $^{2}$, DINGSU FENG ${ }^{3}$ AND CHRISTIAN VON \\ SPERBER $^{4}$ \\ ${ }^{1}$ University of Cologne \\ ${ }^{2}$ University of Göttingen \\ ${ }^{3}$ Abteilung Isotopengeologie \\ ${ }^{4}$ McGill University \\ Presenting Author: d.herwartz@uni-koeln.de
}

Phosphorus is a limiting nutrient for plants in many ecosystems. An in-depth understanding of the processes and pathways that contribute to the bioavailability of $\mathrm{P}$ to plants and microorganisms is essential to understand the environmental phosphorus cycle. It is generally assumed that under P limiting conditions, plants and microorganisms release extracellular enzymes, so called phosphatases, as a strategy to acquire $\mathrm{P}$ from organic phosphorus compounds $\left(\mathrm{P}_{\text {org }}\right)$ [1]. The enzymaticallydriven hydrolysis of $\mathrm{P}_{\text {org }}$ by extracellular phosphatases leads to the incorporation of one or two oxygen from water into the released inorganic phosphate $\left(\mathrm{P}_{\mathrm{i}}\right)$, which is the bioavailable nutrient. Respective kinetic isotope effects associated to enzymatic reactions have been quantified for ${ }^{18} \mathrm{O} /{ }^{16} \mathrm{O}[2,3]$. We have now analyzed the same enzymatic assays for ${ }^{17} \mathrm{O} /{ }^{16} \mathrm{O}$ in order to characterize these reactions in triple oxygen isotope space. The kinetic isotope effects induced by the enzymes alkaline phosphatase, acid phosphatase and phytase clearly differ in triple oxygen isotope space attesting to variable chemical pathways that release $P_{i}$ from $P_{\text {org }}$.

The ubiquitous intracellular enzyme pyrophosphatase catalyzes the exchange of all four phosphate oxygen atoms and leads to isotopic equilibration with oxygen from water. This water can be soil water, evaporitic water from plant leaves, or microbial intracellular water. The latter significantly differs from soil water, because intracellular water can be $30-70 \%$ of metabolic origin as evident from significantly different $\delta^{18} \mathrm{O}$ values [4]. Our triple oxygen isotope analyses show that some $\mathrm{P}_{\text {org }}$ inherits the negative ${ }^{17} \mathrm{O}$-anomaly of air $\mathrm{O}_{2}$ from anomalous metabolic water.

Variations among the triple oxygen isotope ratios may allow the unequivocal identification of the particular enzymatic reactions as well as distinction between ambient soil, evaporitic plant and metabolic water as oxygen sources and opens a new window for the understanding of the phosphorous cycle. Microbial intracellular water can comprise significant fractions atmospheric oxygen and the respective $\mathrm{P}_{\text {org }}$ can be used as a natural tracer in environmental systems.

[1] Hoppe (2003), Hydrobiologia 493, 187-200.

[2] von Sperber et al. (2014), Geochimica et Cosmochimica Acta 125, 519-527.

[3] von Sperber et al. (2015), Biogeosciences 12, 4175-4184. 